\title{
Desire of a Managerial Position and Entrepreneurial Motivation: The Influence of Gender and School Type in the Canary Islands Young People ${ }^{1}$
}

\author{
Flora M. Díaz-Pérez, Olga González-Morales
}

University of La Laguna, Tenerife, Spain.

Email: fdiazp@ull.es

Receive March $15^{\text {th }}, 2011$; revised May $7^{\text {th }}, 2011$; accepted May $17^{\text {th }}, 2011$.

\begin{abstract}
Understanding the factors that determine and influence the choices male and females students make with regard to their studies and future occupations plays a crucial part in the explanation of earnings levels, from both the social and individual perspectives. These factors need to be taken into account in policies to be implemented in order to facilitate the transition of young people to working life. In the present study we consider the role played by the type of school-i.e. whether it is public (state-run) or private-in young people's decisions, in the Canary Islands (Spain). Specifically we study if that factor is influencing male and female students' entrepreneurial motivation and the desire for a managerial occupation. A representative selection of the range of secondary schools was taken for our empirical study, and logistic regression was used, which allows qualitative variables to be included among the predictive variables and enables the analysis of dichotomy phenomena. The desire for a supervisory/managerial occupation and the entrepreneurial motivation are found to be heavily influenced by the type of school (public or private) and in some cases by gender. Specifically, a notable finding of our study is that women tend to show less preference for a supervisory position in their future career, particularly if they have attended a public school.
\end{abstract}

Keywords: Entrepreneurship, Managerial Position, Young People, Gender, Public-Private School

\section{Introduction}

Understanding the factors that determine and influence the choices male and females students make with regard to their studies and future occupations plays a crucial part in the explanation of earnings levels, from both the social and individual perspectives. These factors need to be taken into account therefore in decisions concerning the targeting of human capital investment and the type of policies to be implemented in order to facilitate the transition of young people to working life [1].

In the present study we consider the role played by the type of school i.e. whether it is public (state-run) or private - in young people's decisions, in the Canary Islands (Spain). Specifically we study if that factor is influencing male and female students' entrepreneurial motivation and the desire for a managerial occupation.

Spain's education system is the product of the legisla- tive reforms introduced by the Education Law of 3 October 1990 (known by its acronym LOGSE) ${ }^{2}$, which adapted education and training objectives to the new European Union guidelines. Secondary education in Spain covers compulsory secondary education $(\mathrm{ESO})^{3}$, Bachillerato $^{4}$ (Baccalaureate) and the early stage of vocational training. Careers Guidance departments play a key role in the system in helping students decide which studies to pursue [2], particularly when they progress from one level or cycle to another and have to choose the pathway best suited to their personal characteristics and career interests.

${ }^{1}$ The present study was supported financially by the "Instituto Canario de la Mujer (Canarian Government)", and some empirical results were shown on O. González-Morales Doctoral Thesis.

${ }^{2}$ Official State Journal (BOE), no. 238, 4 October 1990.

${ }^{3}$ This stage (12-16 years) completes basic schooling and is divided into two cycles, each lasting two years.

${ }^{4}$ Begins at the age of 16 and is divided into two years. 
For the above reasons we have focused our study on the evaluation, from the perspective of career guidance teachers, of the potential influence of the type of school (public or private) and of gender on students' employment aspirations (entrepreneurial/managerial or subordinate).

\section{Background}

\subsection{Type of School: Competition between Public and Private Schools}

With regard to the influence of type of school we considerer the competition between public and private school as a first point. Numerous studies show that competition between public and private schools in the same geographical area brings major advantages for both types of education. In this way and with respect to college quality measures, [3] Rumberger and Thomas found that males obtained an earnings advantage for attending a private school, but females did not.

Various models demonstrate the effects on the quality of public education of the presence of private schools in a given area [4-7]. With regard to how school districts modify behaves in response to increased competition, evidence exists that high levels of competition encourage them to allocate a greater proportion of resources to the classroom $[6,8]$.

Couch et al. [7] examine the relationship between private school enrolments and public school performance and find that educational achievement in public schools is higher in localities where a larger percentage of school-age children are enrolled in private schools. The authors conclude therefore that, faced with market competition, public schools may respond by improving the quality of the education delivered.

Specifically, with respect to the factors that determine the size of the private sector in education, James [9] develops a theoretical model which includes the following:

1) excess demand.

2) the existence of heterogeneous demands (due to deep-seated religious and linguistic differences).

3) the supply of non-profit firms in the society concerned.

Moreover, Dee and Hoxby analyses the possible relationship between the quality of public schools and competition from private schools and conclude that public school quality significantly impacts on students and on the demand for private schools $[8,10]$. The results presented in [6] indicate that exogenous variation in competition from private schools does appear to improve the quality of public schools. More specifically, increased competition from private schools leads to higher graduation rates in public schools. However, the main finding of Dee's study is that the demand for private schools and the quality of public schools are simultaneously determined.

\subsection{Choice of Job and Male-Female Labour Market Inequalities}

Available statistical data corroborate the continued existence of a considerable wage gap separating men and women. The causes of this gap have not been accounted for fully. The most common economic explanations have fallen into three categories: the human capital theory, discrimination and concentration of women in certain occupations. The human capital explanation is unsupported by the data: gender differences in experience, education level and employment background account for a mere one-third of wage differences between men and women [11]. Moreover, although women are very much crowded into relatively few occupations, this circumstance in itself does not explain how and why it comes about.

Corcoran and Courant state that women earn less than men even if they hold similar qualifications and the gap is due to the effects of discrimination and socialization [11]. The authors hold that socialization and discrimination operate jointly and concurrently and add further that, at key decision moments, such as the choice of one's first job, the factors acting on such decisions need to be investigated in detail.

Montmarquette et al. show that the 'expected earnings' variable is essential in major choice at college, but there are, however, significant differences in the impact of expected earnings according to gender [12]. Moreover, in choosing an occupation, individuals are less influenced by initial earnings levels and more influenced by the stream of earnings that the occupations are expected to yield.

With respect to the desire for a managerial position, there are many empirical studies that show the existence of a mismatch between men and women senior leadership position all over the world [13]; because of that some authors [14] think that companies and countries can not "afford to continue historic patterns of male dominated leadership" as global competition intensifies, and the opportunity cost of such patterns escalates [13]. Specifically, studies made in Canary Islands demonstrate the existence of hierarchical lines of promotion in industry in which education is a decisive variable in recruitment, with gender also playing an important role in that men tend to be promoted to a greater extent up the employment ladder in firms' Internal Labor Markets. $[15,16]$.

Finally, and in relations to entrepreneurial motive- 
tion, existing literature have shown that, although the probability of being an entrepreneur is highest among older individuals, the likelihood of being a nascent entrepreneur is maximized among young individuals and decreases thereafter $[17,18]$. In Spain the findings of studies made by various authors have shown that over $50 \%$ of the young population surveyed manifested a desire to set up their own company or be self-employed. [19-21]. The results are similar to the findings of studies carried out in the Canary Islands which surveyed students $(70 \%)$ said they would prefer to be self-employed and have the opportunity to earn according to performance [22]. However in those cases gender is not a determinant variable.

With respect to the dependency existing between selfconfidence, fear of failure and, to a less extent, opportunity perceptions, Minniti and Nardone [23] maintained that "individual perceptions may differ from actual abilities and risk levels and are likely to be biased" (p. 236). Similar results were obtained from some labor market studies done in Canary Islands. [24,25].

\subsection{Variables Allowing Public Education to Be Evaluated: The Role of Sociological and Psychological Factors}

Approaches differ also as to which specific variables should be used to measure quality in public education and also with respect to the components of the supply and demand function in public education. In this section we follow the approach found in the literature on the subject, focusing particularly on the role of sociological and psychological variables.

Many studies have shown how demand for private schools is significantly affected by socio-economic status. [26-30]. Other studies have shown that socio-economic characteristics strongly correlate with the level of student achievement. [31,32].

According to Brasington [33], public school quality can be measured using two approaches: the value-added approach and the levels of proficiency test outcomes. The latter, argues Brasington, should be accepted in education literature and should also be valued in the housing market.

Rumberger and Thomas [3] estimate the economic returns to college and include various dimensions of college quality, major and performance. They examine gender differences and consider the following school level variables: a dummy variable to indicate private school, variables indicating the social composition of students, two measures of attractiveness and exclusiveness, indicators of available resources, indicators of the orientation and atmosphere of the school.
In the other hand psychological factors must be considered. Recently models of intention that focus on attitudes have been proposed as a likely explanation for the entrepreneurial process. [34-37]. Those authors have viewed entrepreneurial decisions as a process; in this way Shapero expresses that "willingness to" act is another indispensable element in the process of the new venture decision, because, if the individual is not predisposed to this type of challenge, they will not be likely to act [36].

\section{Methodology and Initial Hypotheses}

\subsection{Contribution}

At the present study we show that differences in the choice of professional career (supervisory vs subordinate occupation) are heavily determined by the type of school (public or private). Therefore, the new aspect included in the present study is the consideration, in the explanatory model, of the occupation to which students aspire in relationship with the type of school and gender. The methodology features a new element also, namely, interviews with careers guidance teachers in schools to ascertain student preferences with respect to their studies and in relationship with future employment. The opinion of careers guidance teachers has been considered for two reasons ${ }^{5}$ :

1) It is part of their job to be aware of the wishes and professional aspirations of the students in their school.

2) Another important role is to advise students on appropriate subject choice, in accordance with their professional aspirations and the situation of the labor market.

\subsection{Initial Hypotheses}

Two hypotheses are put forward for the study:

H1) Desire for a managerial position or the entrepreneurial motivation, in the labor market, is influenced by gender and type of school (public-private).

H2) The above student desires - i.e. promotion aspirations post-education and entrepreneurial motivation determine the type of post occupied in future and thus account for the wage inequalities between men and women.

Consideration of the type of school is a way of characterizing and better understanding the influence of the education system on labor market inequalities. It also affords information for policy makers on how education policy should be directed, depending on whether a

${ }^{5}$ Official Journal of the Canaries (BOC) (1995): Decree 23/1995, 24 February, regulating guidance in schools in the Canary Islands. BOC, 20 March 1995. 
school is public or private, in order to correct gender inequalities.

The objectives and hypotheses addressed in this study aim to illustrate that gender inequalities in the labor market are not caused solely by decisions taken by employers and by workers when they finish their education and enter employment; but decisions taken by students during secondary school determine their future position on the market. Moreover, since the market in western countries rewards managerial positions with greater earnings, this is also a decisive aspect in explaining the unequal situation of men and women. Student motivations regarding their desire for a managerial occupation are a pointer to their promotion aspirations, given that it is difficult to obtain a managerial post if one does not want to. The same happens to the entrepreneurial motivation.

\subsection{Sampling Procedure}

A representative selection of the range of secondary schools in the Canary Islands, a region of Spain, was taken for our empirical study. The schools were selected from the total of 396 making up the school population that year on the seven islands. Interviews were conducted during 2002.

Sampling took into account the difference in the number of public and private schools between the region's two provinces (Santa Cruz de Tenerife and Las Palmas de Gran Canaria).

Proportionate stratified sampling was used, with each strata represented by the school type and area. We began by carrying out simple random sampling to enable us to calculate the sample size and then allocated the proportions, i.e. distribution of the sample among the strata proportionately to size to ensure they were representative of schools in the population segment studied.

The choice of school was entirely random, respecting the proportion of each stratum. The sample finally comprised 248 schools.

The maximum estimation error for the total sample, following the interviews with the careers teachers, was \pm $4.1 \%$, with $95.5 \%$ reliability.

To study the differences according to the type of school and gender contingency tables were drawn up and the Chi-squared test was applied to check if the frequency distributions among two variables corresponded to a model distribution. A probability of less than 0.05 shows that the observed distribution does not behave as expected and significant differences exist therefore between the different populations segments studied.

As regards the general characteristics of the sample, $50 \%$ of those interviewed were aged between 35 and 44 and $60 \%$ were women. $44 \%$ of the interviews were con- ducted with careers guidance teachers, $22 \%$ with school principals, $29 \%$ with heads of studies, and the remaining $5 \%$ with other members of staff at the schools. It is worth noting that only $21.4 \%$ of the careers teachers were part of the management team in their school.

\section{Results}

According to the findings set out in this paper, differences between the labor market situation of men and women cannot therefore be explained on the basis of academic results alone. Put another way, even if women opt for intensive study of mathematics, which would normally produce higher earnings on the market [38], empirical evidence shows that they generally occupy a lower rung in the jobs' hierarchy and therefore earn less than men. [14,15].

In our paper and from the perceptions of career guidance teachers, the desire for a supervisory/managerial occupation and the entrepreneurial motivation are found to be heavily influenced by the type of school (public or private) and in some cases by gender. Specifically, a notable finding of our study is that women tend to show less preference for a supervisory position in their future career, particularly if they have attended a public school.

Otherwise, Albrecht et al. using regression analysis for 1998 Swedish data find that "even after extensive control for gender differences in age, education (both level and field), sector industry, and occupation, the glass ceiling effect found in the raw data persists to a considerable extent" [39]. To the outcome noted by Albrecht et al. and Rumberger and Thomas, [3] and [39], the present study incorporates a new element, namely, the decisive role played by school type - i.e. Whether it is public (state-run) or private - in decisions taken by secondary school students concerning their future type of occupation (managerial/entrepreneur or subordinate).

\subsection{The Influence of Gender and Type of School on the Desire for a Managerial Position}

The issues students need to take into account when making their subject choices include their professional interests and the type of career they would like to pursue to develop their skills and aptitudes. In some cases the choice of one or other pathway can be an obstacle to the pursuit of certain careers.

Decisions of this nature are often taken with a degree of uncertainty, all the more so if little information on alternatives is available to young people, or when their interests and goals are ill-defined or when they make their choice too early, often with potentially irreversible consequences. Here the role of the careers guidance teacher is crucial given that a student's decision will, in 
the long term, entail an opportunity cost in economic terms and also at personal level [40].

For this reason we believe that the gender and type of school variables influence the choice and to some extent will largely determine the different labor market statuses, depending on whether the individual concerned is male or female and attends a public or a private school.

Table 1, showing respondents' answers concerning students' professional interests, reveals significant gender differences, which increase considerably when the type of school is factored into the analysis.

The analysis of the responses to questions concerning the type of job (Table 2) reveals important differences in each of the two variables. To begin with, careers teachers consider that women are less keen than men for a managerial or supervisory position. This impression is evidenced by the 37-point difference between women $(21.2 \%)$ and men $(58.5 \%)$. Furthermore, there is a spectacular difference depending on whether the careers teacher works in a public or private school. When asked about students' desires for a managerial or supervisory occupation, $68.3 \%$ of teachers in private schools are of the opinion that their students have high aspirations, compared to just $17.9 \%$ in pubic schools.

Such marked differences merit special attention. We will apply once more the previous statistical analysis to

Table 1. Professional interests by gender and type of school.

\begin{tabular}{|c|c|c|c|c|}
\hline Professional interests & Female & Male & Public & Private \\
\hline Farming or fisheries & 4.3 & 3.5 & 5.7 & \\
\hline Construction & 2.1 & 1.2 & 2.5 & \\
\hline $\begin{array}{l}\text { Electricity, gas, water, alternative } \\
\text { energies }\end{array}$ & & 2.4 & 0.6 & 1.5 \\
\hline Crafts & & 1.2 & 0.6 & \\
\hline Transport & 0.7 & & 0.6 & \\
\hline $\begin{array}{l}\text { Equipment and installation } \\
\text { maintenance }\end{array}$ & 20.1 & 16.5 & 23.3 & 7.6 \\
\hline Retail (including travel agents) & 25.9 & 24.7 & 24.1 & 28.9 \\
\hline Security and protection & 0.7 & 1.2 & 1.3 & \\
\hline $\begin{array}{l}\text { Communication and personal } \\
\text { relations }\end{array}$ & 2.9 & 9.4 & 3.2 & 10.6 \\
\hline $\begin{array}{l}\text { Personal and/or community } \\
\text { services }\end{array}$ & 18.7 & 12.8 & 19.0 & 10.6 \\
\hline Hotel/catering & 5.8 & 8.2 & 8.9 & 1.5 \\
\hline Plastic arts and artistic expression & 2.9 & 2.4 & 2.5 & 3.0 \\
\hline Professional consultancy & 9.4 & 11.7 & 3.2 & 27.3 \\
\hline Clerical, public sector & 1.5 & 2.4 & 1.3 & 3.0 \\
\hline Teaching & 2.1 & & 1.3 & 1.5 \\
\hline Scientific research & & 1.2 & 0.6 & \\
\hline Health & 2.9 & 1.2 & 1.3 & 4.5 \\
\hline
\end{tabular}

Gender $\mathrm{p} \leq 0.000$, Type of school $\mathrm{p} \leq 0.000$.
Table 2. Type of job according to gender and school type.

\begin{tabular}{lcccc}
\hline Job & Female & Male & Public & Private \\
\hline Directors/managers & 21.2 & 58.5 & 17.9 & 68.3 \\
Clerical & 38.1 & 21.5 & 37.4 & 21.7 \\
Personal services and security & 16.1 & 4.6 & 13.8 & 8.3 \\
staff & 4.3 & 3.1 & 4.9 & 1.7 \\
Armed Forces & 5.1 & & 4.9 & \\
Skilled farming/fisheries workers & 0.8 & 3.1 & 2.4 & \\
Skilled construction workers & 0.8 & & 0.8 & \\
Skilled operative, industry and & 0.5 & 7.7 & 12.2 & \\
similar & 8.5 & & 4.9 & \\
Machine operators/drivers & 5.1 & & 0.8 & \\
Shop assistants & & 1.5 & 0.8 \\
Labourers and unskilled workers & & &
\end{tabular}

Gender $\mathrm{p} \leq 0.000$, Type of school $\mathrm{p} \leq 0.000$.

see if a new model can be obtained to evaluate the influence of the gender and school type variables on the desire for a supervisory position or a subordinate occupation.

We will firstly group answers into two blocks: one managerial positions - comprising answers relating to directors and managers, the other-subordinate occupation-comprising all other answers given by the careers teachers (see Tables 3 and $\mathbf{4}$ ).

The considerable influence of the independent variables (gender and type of school) is evident.

In order to ascertain if a link exists between the dependent variable (type of job) and the independent variables (type of school, TS, and gender, G) and, if so, to measure the extent of the link and estimate it in terms of the correlation or association of a given choice, we will use logistic regression, which allows qualitative variables to be included among the predictive variables and enables the analysis of dichotomy phenomena [41].

In this case the dependent variable takes the dichotomy form of managerial positions and subordinate occupations.

Table 3. Occupation by gender.

\begin{tabular}{ccc}
\hline & Male & Female \\
\hline Managerial position & 58.5 & 21.2 \\
Subordinate occupation & 41.5 & 78.8 \\
\hline
\end{tabular}

$\mathrm{p} \leq 0.000$.

Table 4. Occupation by type of school.

\begin{tabular}{lcc}
\hline & Public & Private \\
\hline Managerial position & 17.9 & 68.3 \\
Subordinate occupation & 82.1 & 31.7 \\
\hline
\end{tabular}

$\mathrm{p} \leq 0.000$. 
The SPSS statistics package (version 11.5) is used to estimate the model parameters. The statistical technique directly estimates the likelihood of the occurrence of an event, in this case $p=p r$ (subordinate occupation). Hence, the likelihood that it will not occur is expressed as $1-p$, i.e. $1-p=p r$ (managerial position). The value of $p$ is determined analytically by the following coefficient:

$$
p=\frac{\mathrm{e}^{z}}{1+\mathrm{e}^{z}}
$$

where $Z=B_{0}+B_{1} X_{1}+B_{2} X_{2}+\cdots B_{n} X_{n}$; in our study, since we are using two independent variables, $Z=B_{0}+$ $B_{1} X_{1}+B_{2} X_{2}$.

The model is non-linear and an iterative algorithm is needed for the estimation therefore. We use the maximum likeness method and the estimated coefficients thus make our data more likely.

Table 5 gives the coding for the variables while Table 6 shows the model coefficient estimators.

The initial values of the dependent variable were 1 for the managerial positions and 2 for subordinate occupations, although these were recoded as 0 and 1 respectively by the statistics program.

The result of the analysis is as follows:

$p=p r$ (subordinate occupations), the value of $Z$ being $Z=3.1941-0.9351(T S)-1.5315(G)$

$$
p=\frac{\mathrm{e}^{3.1941-0.9351(T S)-1.5315(G)}}{1+\mathrm{e}^{3.1941-0.9351(T S)-1.5315(G)}}
$$

The negative sign for $R$ indicates that as the variable values increase - male, from a private school - the dependent variable values decrease and, consequently, male students in private schools can be said to be more likely to want to occupy a managerial position in their professional career.

\subsection{Entrepreneurial Motivation}

Turning to students' preference for self-employment, the results of our study indicate that particularly in public schools, careers teachers and principals consider that students do not view self-employment as a career option.

\begin{tabular}{|c|c|c|}
\hline & VARIABLES & CODING \\
\hline Dependent & Type of job & $\begin{array}{l}0=\text { managerial positions } \\
1=\text { subordinate occupations }\end{array}$ \\
\hline \multirow[t]{2}{*}{ Independent } & Type of school (TS) & $\begin{array}{l}1=\text { Public } \\
2=\text { Private with govt. funding } \\
3=\text { Private }\end{array}$ \\
\hline & Gender (G) & $\begin{array}{l}1=\text { Women } \\
2=\text { Men }\end{array}$ \\
\hline
\end{tabular}

Table 5. Model variables.
Regarding the gender variable, the results shown in Figure 1 indicate that gender seems to have less influence than school type on students' desires to enter selfemployment. To verify this statement, and to check whether there is some form of association between the variables, we will use multiple correspondence analyse. We begin with the Burt matrix, in which each block is a sub-matrix formed by contingency tables of pairs of variables and their respective modalities. The sub-matrices on the diagonal are formed by each variable with itself and hence only non-null values appear on the diagonal. Given that the rows and column represent the same modalities, the study of both will produce the same outcome and hence we only give the results for the examination of the row points. 2 axes are considered since together they explain $80.1 \%$ of the total point inertia. The value of the statistic $\chi^{2}$ and its significance less than 0.05 - enables us to reject the null hypothesis of independence of the variables.

Table 7 shows the dimension scores or distances to origin, the absolute contributions of each modality and variable to the inertia of the new axes, as well as the relative contributions, i.e. the correlations of each modality with the new axes.

\subsection{Axis Analysis}

On axis 1 the modalities best represented and which contrast with each other are, on the positive side, private school and self-employment, and on the negative - public school and employment. On axis 2 female is located on the positive side and male on the negative side (see Figure 2).

In sum, the most important conclusion of this analysis is that students in public schools differ markedly from their private school counterparts. The latter are, relatively speaking, more likely to consider self-employment as a career choice, whereas the former prefer to work for others. The gender variable is not found to be associated with entrepreneurial motivation in the studied population.

\section{Conclusions and Recommendations}

The study presented here examines the preferences of secondary school students concerning type of occupation. The analysis is based on the gender of the students and the type of school (public or private).

The results outlined in this paper show clearly that, in the opinion of careers teachers, the decisions taken by public school students concerning their future careers tend to run contrary to advantageous positions in labor market and gender equality policies. Female students in public schools aspire to positions generally associated with poorer labor market conditions. 
Table 6. Model coefficient estimators.

Estimation Terminated at Iteration Number 3 Because

Log Likelihood Decreased by Less than, 01 Percent.

Iteration History:

\begin{tabular}{ccccc}
\hline Iteration & Log Likelihood & Constant & TS & G \\
\hline 1 & $-145,14048$ & 2,6390601 &,- 67388364 & $-1,3295082$ \\
2 & $-144,22112$ & 3,1360759 &,- 90283261 & $-1,5139168$ \\
3 & $-144,20930$ & 3,1940949 &,- 93511066 & $-1,5314524$ \\
\hline
\end{tabular}

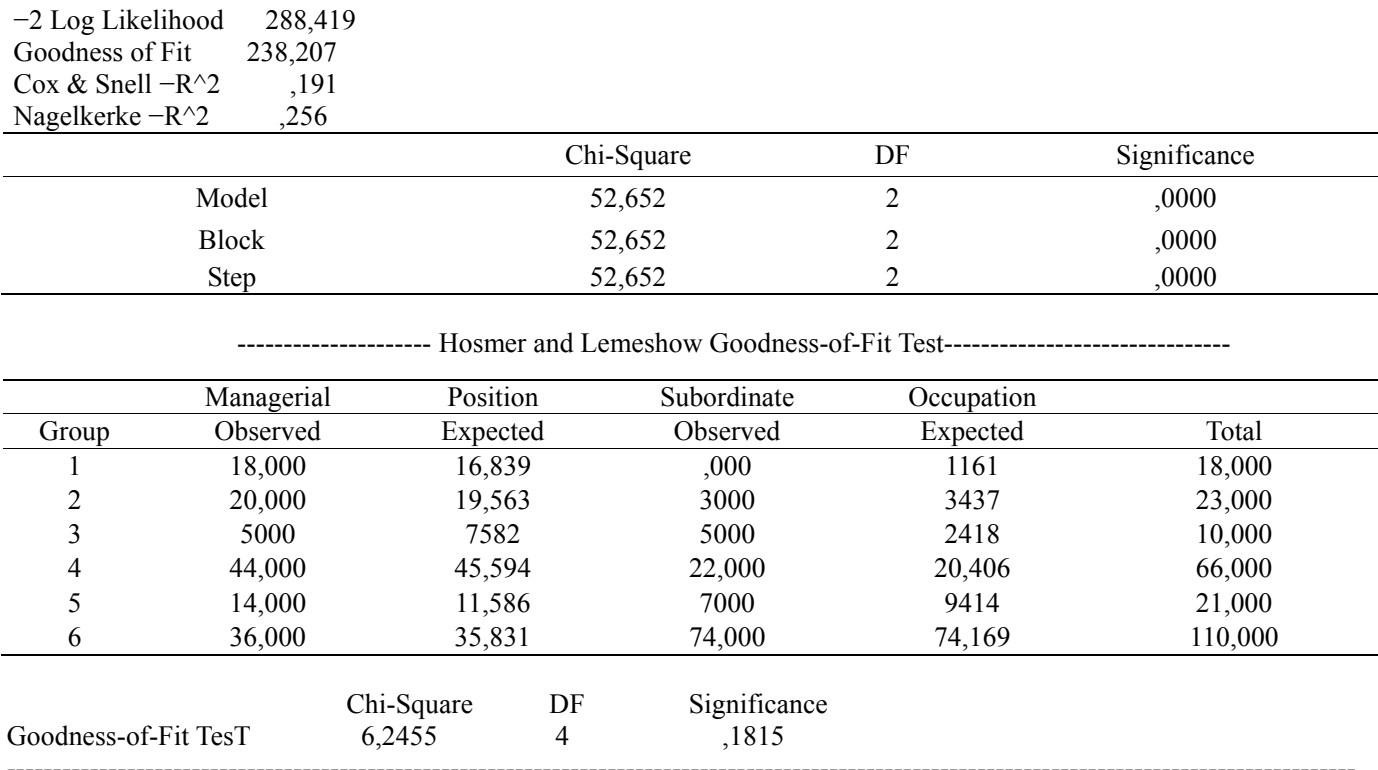

Classification Table For Puesto2

The Cut Value Is , 50

\begin{tabular}{|c|c|c|c|}
\hline & \multicolumn{2}{|c|}{ Predicted } & \\
\hline & $\begin{array}{l}\text { Managerial } \\
\text { Position }\end{array}$ & $\begin{array}{l}\text { Subordinate } \\
\text { Occupation }\end{array}$ & Percent \\
\hline Observed & 1 & 2 & Correct \\
\hline $\begin{array}{l}\text { Managerial } \\
\text { Position }\end{array}$ & 101 & 36 & $73,72 \%$ \\
\hline $\begin{array}{l}\text { Subordinate } \\
\text { Occupation }\end{array}$ & 37 & 74 & $66,67 \%$ \\
\hline
\end{tabular}

Overall $70.56 \%$

Variables in the Equation

$\begin{array}{ccccccc}\text { Variable } & \text { B } & \text { S.E. } & \text { Wald } & \text { df } & \text { Sig } & \text { R } \\ \text { TS } & -, 9351 & , 2512 & 13,8552 & 1 & , 0002 & -, 1864 \\ \text { G } & -1,5315 & , 2955 & 26,8675 & 1 & , 0000 & -, 2700 \\ \text { Constant } & 3,1941 & , 5366 & 35,4257 & 1 & , 0000 & \end{array}$

\begin{tabular}{lcccc}
\multicolumn{5}{c}{$95 \%$ CI for $\operatorname{Exp}(\mathrm{B})$} \\
Variable & $\operatorname{Exp}(\mathrm{B})$ & Lower & Upper & \\
TS &, 3925 &, 2399 &, 6423 & \\
G &, 2162 &, 1212 &, 3858 & \\
& & & & \\
Correlation & Matrix: & & & G \\
& & Constant & TS &,- 75415 \\
Constant & 1,00000 &,- 60239 &, 00227 \\
TS &,- 60239 & 1,00000 & 1,00000 \\
G & &,- 75415 &, 00227 &
\end{tabular}




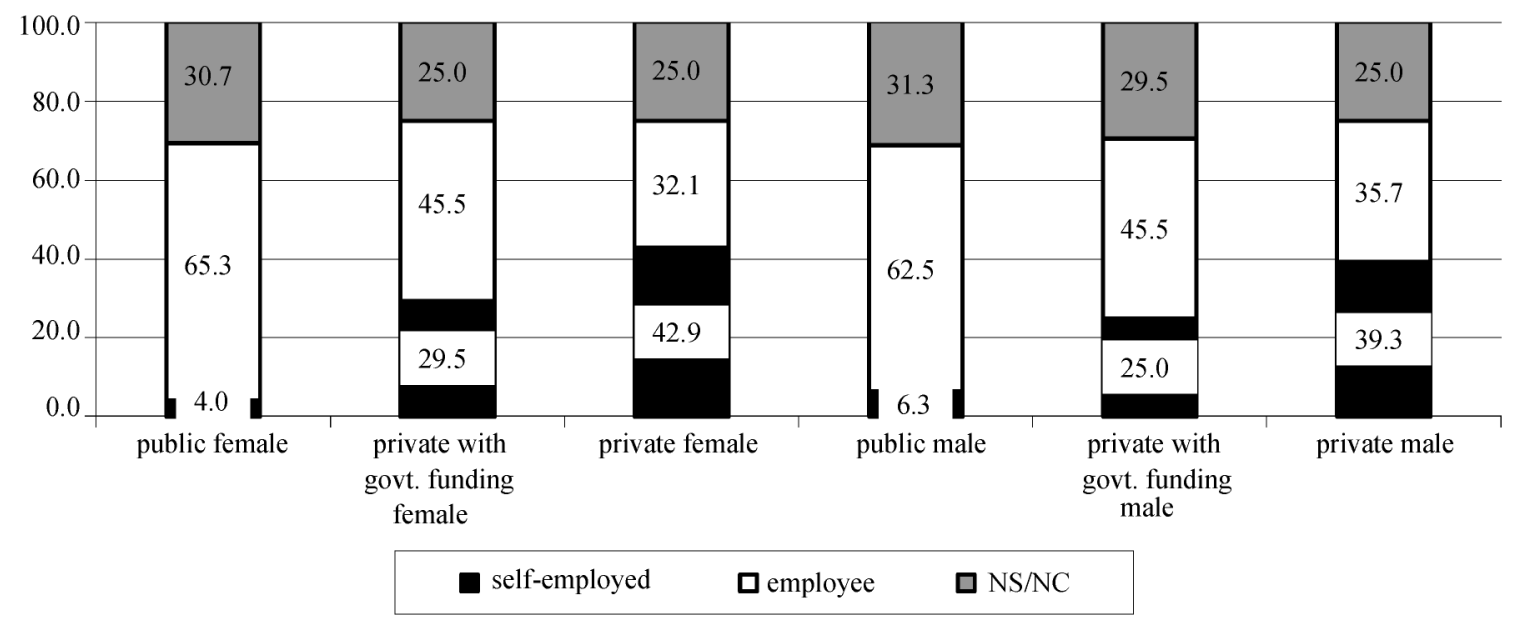

Figure 1. Self-employed or employee.

Table 7. Examination of row points ${ }^{(a)}$.

\begin{tabular}{|c|c|c|c|c|c|c|c|c|c|}
\hline \multirow[t]{3}{*}{$\mathrm{m} 1$} & \multirow[t]{3}{*}{ Mass } & \multicolumn{2}{|c|}{ Dimension score } & \multirow[t]{3}{*}{ Inertia } & \multicolumn{5}{|c|}{ Contribution } \\
\hline & & \multirow{2}{*}{1} & \multirow{2}{*}{2} & & \multicolumn{2}{|c|}{ Of scores to the dimension inertia } & \multicolumn{3}{|c|}{ Of the dimension to the point inertia } \\
\hline & & & & & 1 & 2 & 1 & 2 & Total \\
\hline Public & 0.225 & -0.628 & 0.181 & 0.052 & 0.204 & 0.023 & 0.736 & 0.045 & 0.781 \\
\hline Private & 0.108 & 0.760 & -0.194 & 0.060 & 0.144 & 0.013 & 0.453 & 0.022 & 0.475 \\
\hline Employment & 0.209 & -0.489 & 0.100 & 0.038 & 0.115 & 0.006 & 0.570 & 0.018 & 0.588 \\
\hline Self-employment & 0.124 & 1.263 & -0.320 & 0.102 & 0.456 & 0.039 & 0.842 & 0.041 & 0.882 \\
\hline Female & 0.198 & 0.281 & 0.782 & 0.047 & 0.036 & 0.372 & 0.144 & 0.833 & 0.977 \\
\hline Male & 0.136 & -0.377 & -1.144 & 0.067 & 0.044 & 0.547 & 0.125 & 0.859 & 0.984 \\
\hline Total & 1.000 & & & 0.367 & 1.000 & 1.000 & & & \\
\hline
\end{tabular}

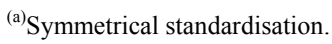

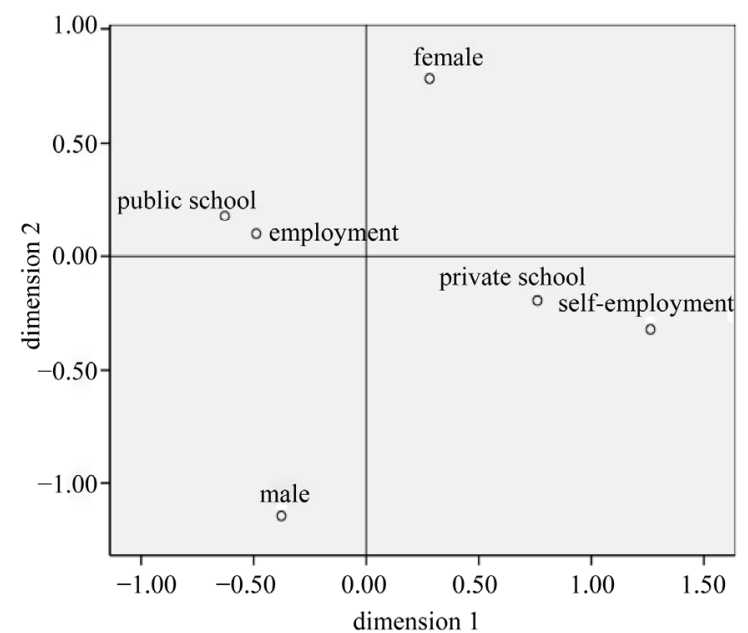

Figure 2. Female is located on the positive side and male on the negative side.
The question is whether the above result reflects inappropriate implementation of education policy in public schools. In the light of prior approaches, the results of our study should serve to redirect education policy rather than to question the efficiency of the allocation of public resources in education. It should help redefine the role of teachers providing careers guidance in schools, to ensure greater attention is paid to the choices made by students, both male and female, and point them in the direction of studies and careers better geared to the best labor market conditions.

In sum, education policy needs to be reviewed and integrated with gender policy. In this respect, future research should include variables that measure the quality of public schools and the extent to which students are advised to pursue careers offering the best employment possibilities. 
Furthermore, the answers given by careers teachers in public schools give cause for reflection on the need to improve certain aspects of career guidance. The results of our study highlight the influence of the type of school on young people's choice of occupations they hope to pursue. The opinion of careers teachers with respect to the preferences and aspirations of their students discriminates negatively against females. Furthermore, teachers working in government-funded private schools and especially those in fully private schools consider their students to have higher aspirations concerning their future employment.

The results obtained also underline the need for further studies to complete these findings, and take into account different situations.

\section{REFERENCES}

[1] OCDE, "De la Formation Initiale à la Vie Active: Faciliter Les Transitions," OCDE, Paris, 2000.

[2] L. Chisholm, "Los Jóvenes Europeos y la Orientación Profesional: Qué Hacer Que Necesiten y Deseen Los Jóvenes?” CEDEFOP, Salónica, 1996.

[3] R. W. Rumberger and S. Thomas, "The Economic Returns to College Major, Quality and Performance: A Multilevel Analysis of Recent Graduates," Economics of Education Review, Vol. 12, No. 1, 1993, pp. 1-19. doi:10.1016/0272-7757(93)90040-N

[4] D. M. Brasington, "Demand and Supply of Public School Quality in Metropolitan Areas: The Role of Private Schools," Journal of Regional Science, Vol. 40, No. 3, 2000, pp. 583-605. doi:10.1111/0022-4146.00189

[5] D. Goldhaber, "An Endogenous Model of Public School Expenditures and Private School Enrollment," Journal of Urban Economics, Vol. 46, No. 1, 1999, pp. 106-128. doi:10.1006/juec.1998.2115

[6] T. Dee, "Expense Preference and Student Achievement in School Districts," Working Paper, Department of Economics, University of Maryland, Maryland, 1997.

[7] J. F. Couch, W. F. Shughart and A. L. Williams, "Private School Enrollment and Public School Performance," Public Choice, Vol. 76, No. 3, 1993, pp. 301-312. doi:10.1007/BF01053301

[8] C. M. Hoxby, "Do Private Schools Provide Competition for Public Schools?" Working paper No. 4978, Master's Thesis, National Bureau of Economic Research, Cambridge, 1995.

[9] E. James, "The Public/Private Division of Responsibility for Education: An International Comparison," Economics of Education Review, Vol. 6, No. 1, 1987, pp. 1-14. doi:10.1016/0272-7757(87)90028-8

[10] T. S. Dee, "Competition and the Quality of Public School," Economics of Education Review, Vol. 17, No. 4, 1998, pp. 419-427. doi:10.1016/S0272-7757(97)00040-X

[11] M. E. Corcoran and P. N. Courant, "Sex Role Socializa- tion and Labor Market Outcomes," The American Economic Review, Vol. 75, No. 2, 1985, pp. 275-279.

[12] C. Montmarquette, C. Cannings and S. Mahseredjian, "How Do Young People Choose College Majors?" Economic of Education Review, Vol. 21, No. 6, 2002, pp. 217. doi:10.1016/S0272-7757(01)00054-1

[13] N. J. Adler, L. W. Brody and J. S. Osland, "The Women Global Leadership Forum: Enhancing One Company's Global Leadership Capability 2," Human Resources Management, Vol. 39, No. 2-3, 2000, pp. 209-225. doi:10.1002/1099-050X(200022/23)39:2/3<209::AIDHRM10>3.0.CO;2-Y

[14] A. B. Fisher, "When Will Women Get to the Top?" Fortune, Vol. 21, 1992, pp. 44-56.

[15] F. M. Díaz-Pérez, "Educación y Promoción Laboral en un Mercado Interno de Trabajo Del Sector Industrial," EKONOMIAZ (Revista Vasca de Economía), Vol. 22, 1992, pp. 248-267.

[16] F. M. Díaz-Pérez, "Methodology for Determine the Promotion Lines and Ports of Entry of an Industrial Internal Labor Market," International Journal of Manpower, Vol. 14, No. 1, 1993, pp. 40-58. doi:10.1108/01437729310023233

[17] M. Levesque and M. Minniti, "The Effect of Aging on Entrepreneurial Behaviour," The Journal of Business Venturing, Vol. 21, No. 2, 2006, pp. 177-194. doi:10.1016/j.jbusvent.2005.04.003

[18] D. G. Blanchflower, "Self-Employment: More May Not Be Better," NBER Working Paper No. 10286, 12 February 2004.

[19] E. A. Rubio López, E. Cordón-Pozo and A. L. Martín, "Actitudes Hacia la Creación de Empresas: Un Modelo Explicativo," Revista Europea de Dirección y Economía de la Empresa, Vol. 8, No. 3, 1999, pp. 37-51.

[20] J. M. S. Palacio and A. R. Cano, "Actitudes Hacia la Creación de Empresas; Un Estudio Empírico Aplicado a Los Estudiantes de Relacione Laborales de la Universidad de Valencia," II Jornadas Nacionales sobre la enseñanza en las Relaciones Laborales, Salam-Anca, Junio, 1997.

[21] A. C. García, "Capacidades Empresariales y Directivas Como Explicación de la Competitividad," V Congreso Nacional de Economía, Las Palmas de Gran Canaria, Diciembre 1995.

[22] O. G. Morales, “Análisis de la Motivación Empresarial en la Población Juvenil Según Tipo de Centro," Revista de Educación, Vol. 331, 2003, pp. 533-559.

[23] M. Minniti and C. Nardone, "Being in Someone Else's Shoes: The Role of Gender in Nascent Entrepreneurship," Small Business Economics, Vol. 28, No. 2-3. 2007, pp. 223-238. doi:10.1007/s11187-006-9017-y

[24] F. M. Díaz-Pérez, et al., "Investigación Sobre la Situación de la Mujer en el Mercado de Trabajo Atendiendo a Los Requerimientos de la Demanda," Instituto Canario de la Mujer, ejemplar policopiado, Sta. Cruz de Tenerife, 2001.

[25] F. M. Díaz-Pérez, M. Bonnet-Escuela and C. Fernández- 
Hernández, "Mujer Emprendedora en un Entorno Rural: El Caso de la Isla de La Palma," Asociación de Turismo Rural Isla Bonita, .Sta. Cruz de Tenerife, 2000.

[26] H. Lankford and J. Wyckoff, "Primary and Secondary School Choice among Public and Religious Alternative," Economics of Education Review, Vol. 11, No. 4, 1992, pp. 317-337. doi:10.1016/0272-7757(92)90040-A

[27] J. E. Long and E. F. Toma, "The Determinants of Private School Attendance, 1970-1980," Review of Economics and Statistics, Vol. 70, No. 2, 1988, pp. 351-357. doi: $10.2307 / 1928323$

[28] E. West and H. Palsson, "Parental Choice of School Characteristics: Estimation Using State-Wide Data," Economic Inquiry, Vol. 26, 1988, pp. 725-740.

[29] J. Martinez-Vázquez and B. Seaman, "Private Schooling and the Tiebout Hypothesis," Public Finance Quartely, Vol. 13, No. 3, 1985, pp. 293-318.

[30] J. M. Gemello and J. Osman, "Estimating the Demand for Private School Enrolment," American Journal of Education, Vol. 92, No. 3, 1984, pp. 262-279. doi: $10.1086 / 443749$

[31] R. Haveman and B. Wolfe, "The Determinants of Children's Attainment: A Review of Methods and Findings," Journal of Economic Literature, Vol. 33, No. 4, 1995, pp. 1829-1878.

[32] E. Hanushek, "The Economics of Schooling: Production and Efficiency in Public Schools," Journal of Economic Literature, Vol. 24, No. 3, 1986, pp. 1141-1177.

[33] D. M. Brasington, "The Supply of Public School Quality," Economics of Education Review, Vol. 22, No. 4, 2002, pp. 367-377. doi:10.1016/S0272-7757(02)00074-2
[34] S. T. Morales-Galdrón and S. Roig, "The New Venture Decisions: An Analysis Based on the GEM Project Database," International Entrepreneurship and Management Journal, Vol. 1, No. 4, 2005, pp. 479-99. doi:10.1007/s11365-005-4774-7

[35] D. R. Gnyawali and D. S. Fogel, "Environments for Entrepreneurship Development: Key Dimensions and Research Implications," Entrepreneurship Theory and Practice, Vol. 18, No. 4, 1994, pp. 43-62.

[36] A. Shapero, "The Entrepreneurial Event," In: C. A. Kent Ed., The Environment for Entrepreneurship, Lexington Books, Toronto, 1984, pp. 21-40.

[37] A. Shapero and L. Sokol, "The Social Dimensions of Entrepreneurship," In: C. A. Kent, D. L. Sexton and K. H. Vespers Eds., Encyclopedia of Entrepreneurship, Prentice Hall, Englewood Cliffs, 1982, pp. 72-90.

[38] M. Paglin and M. Rufolo, "Heterogeneous Human Capital, Occupational Choice, and Male-Female Earnings Differences," Journal of Labor Economics, Vol. 8, No. 1, 1990, pp. 123-144. doi:10.1086/298239

[39] J. Albrecht, A. Björklund and S. Vroman, "Is There a Glass Ceiling in Sweden," Journal of Labor Economics, Vol. 21, No. 1, 2003, pp. 145. doi:10.1086/344126

[40] CEDEFOP, "Formación Para Una Sociedad de Cambio," Informe Acerca de la Situación Actual de la Investigación Sobre la Formación Profesional en Europa, CEDEFOP, Salónica, 1999.

[41] J. F. Hair, R. E. Anderson, R. L. Tatham and W. C. Black, "Multivariate Data Analysis," Prentice-Hall, Upper Saddle River, 1998. 